\title{
Congress as manager: oversight hearings and agency morale
}

JOHN D. MARVEL

School of Policy, Government, and International Affairs, George Mason University, USA

E-mail: jmarvel@gmu.edu

ROBERT J. MCGRATH

School of Policy, Government, and International Affairs, George Mason University, USA

E-mail: rmcgrat2@gmu.edu

\begin{abstract}
Federal agencies perform many important tasks, from guarding against terrorist plots to mailing social security checks. A key question is whether Congress can effectively manage such a large and influential bureaucracy. We argue that Congress, in using oversight to ensure agency responsiveness to legislative preferences, risks harming agency morale, which could have negative long-run effects on performance and the implementation of public policy. More specifically, we argue that oversight's effects on agency morale are conditional on whether oversight is adversarial or friendly. We assess our claims using a novel data set of the frequency and tone of hearings in which federal agencies are called to testify before Congress from 1999 to 2011 and merge it with data on agency autonomy and job satisfaction. Our findings suggest that agency morale is sensitive to congressional oversight attention, and thus speak to questions regarding democratic accountability, congressional policymaking and the implementation of public policy.
\end{abstract}

Key words: bureaucracy, congress, oversight, policy implementation, public management

The agencies that comprise the federal government's executive branch do many things: they protect the environment, guard against foreign and domestic threats to national security, mail millions of social security checks each month and perform many additional functions, some more glamorous than others. Given that the federal bureaucracy is a nonelectoral institution, Congress is charged with overseeing the execution of these tasks. In particular, congressional committees monitor the bureaucracy through oversight hearings, often attempting to increase agency responsiveness to congressional policy preferences. Yet, scholarship has paid scant attention to the possibility that such oversight may have significant 
managerial consequences. In particular, theory suggests that oversight may, at least conditionally, negatively affect agency morale, particularly as reflected in agencies' collective senses of autonomy and job satisfaction that is, an empirical, as well as a theoretical, trade-off may exist between political responsiveness and agency autonomy. We assessed this possibility, examining the link between oversight and survey-based measures of morale, and found that congressional oversight, when it is adversarial in tone, can indeed have negative consequences for the functioning of bureaucracy. Yet, we also found that more "friendly" congressional attention can actually improve agency morale.

Our research speaks to persistent questions concerning the correct balance between politics and administration. The impact of politics on policy implementation has been the subject of long-standing scholarly debate, particularly within public administration (Waldo 1948). Echoing arguments from the Progressive Era (Wilson 1887), contemporary government reform movements such as the New Public Management advance the argument that politics interferes with agencies' fulfilment of their duties (see, e.g. Light 2006). On the other hand, some have argued that politics and administration are inextricably intertwined, and that attempts to neatly separate them are hopeless and naive (Waldo 1948; Rosenbloom 1993). By examining whether and under which conditions congressional oversight is related to agency morale, we aim to make an empirical contribution to this debate. We also contribute to the burgeoning public management literature on organisational performance. Although the notion that political actors influence agencies is central to this literature's prominent theories (e.g. O’Toole and Meier 1999; Rainey and Steinbauer 1999), very little empirical research addresses whether there is in fact a relationship between the activities of these actors and agency morale - a variable that theory and empirical evidence suggest will affect performance. ${ }^{1}$

We seek to synthesise and contribute to two distinct, but related, fields of research. Studies in political science have traditionally been concerned with questions of congressional monitoring and control of bureaucratic outputs and policy (McCubbins and Schwartz 1984; Bendor et al. 1985; Moe 1989; Ferejohn and Shipan 1990; Balla 1998; Wood and Bohte 2004). This is a crucially important issue for a democratic system of government. If duly elected political actors must rely on unelected bureaucrats to implement policy programmes, control and responsiveness are normative imperatives (see, e.g. Finer 1941). Research in public administration, on the other hand,

${ }^{1}$ Although we argue that morale is related to organisational performance, we are careful not to conflate the two concepts. Indeed, we expect to see future research make more direct assessments of the relationship between congressional oversight and agency performance. 
has focussed on the roles of professional norms and ethics in constraining bureaucratic policy implementation. In this view, public agencies should be subject to internal constraints (the so-called "inner check"), yet minimally encumbered by the intrusion of political actors (Friedrich 1940). These two perspectives - democratic control of public agencies enforced by external political actors versus professional democratic norms developed through internal discipline ${ }^{2}-$ are often seen as driving contemporary normative debates across political science and public administration. We seek to test the implicit claim of the latter perspective that political intervention can serve to limit agency discretion in deleterious and counterproductive ways (Behn 1995). In particular, we utilise novel data on oversight hearings directed at particular agencies from 1999 through 2011, and assess whether increases in oversight attention affect agencies' collective feelings of autonomy and job satisfaction.

We begin by discussing agency morale and its importance. As theory suggests that morale is positively associated with agency performance, as well as with work attitudes and work behaviours that feed into performance, we see it as particularly worthy of empirical attention. We then argue that congressional oversight is likely to affect agency morale, but that the direction of these effects should depend on the content and tone of the oversight. Next, we describe our data and empirical strategy, paying particular attention to our measures of oversight and agency morale. After presenting our results, we close with a discussion of our findings' practical and theoretical implications. The main takeaway is that oversight seems to negatively affect morale, but only when the oversight is adversarial and negative in tone. In fact, we provide evidence that so-called "advocacy" oversight, on the other hand, can actually bolster agency morale (Aberbach 1990).

\section{The importance of agency morale}

Part of the job of any manager, in any organisational setting, is to motivate employees. Doing so involves cultivating employee work attitudes (e.g. job satisfaction, organisational commitment) and behaviours (e.g. arriving to work on time, aiding coworkers) that are thought to be associated with individual-and organisational-level performance. In exercising its oversight function, however, Congress is not necessarily interested in doing these things. ${ }^{3}$ Instead, it is primarily interested in ensuring federal agencies'

2 Or selection of a "representative bureaucracy" (e.g. Meier 1975; Meier and Nigro 1976).

${ }^{3}$ We recognise that Congress is not, strictly speaking, the "boss" of the federal bureaucracy. Yet, we use workplace terminology as a metaphor for the principal-agent relationship that is said 
responsiveness to legislative preferences. ${ }^{4}$ However, in pursuing responsiveness, Congress can unwittingly harm agency morale. Before fully developing this argument below, we define the empirical focus of our study agency morale - and discuss its importance for agency performance.

We use the term "agency morale" to denote agency employees' collective feelings of autonomy and job satisfaction. Theory and evidence from the organisational behaviour literature suggest that, at the individual level, both of these traits are positively related to job performance. In a meta-analysis of 312 independent samples, Judge et al. (2001) found a correlation between job satisfaction and job performance of 0.30 . Similarly, in a meta-analysis of 101 independent samples, Spector (1986) found a correlation between autonomy and job performance of 0.26 . In fact, these correlations likely underestimate the total impact of job satisfaction and autonomy on performance, given that both are associated with numerous other work attitudes and behaviours that are themselves related to performance. These include, for instance, organisational commitment, role conflict, role ambiguity, emotional distress, absenteeism, turnover intention and actual turnover (Spector 1986; Mathieu and Zajac 1990; Tett and Meyer 1993; Meyer et al. 2002; Riketta 2002).

Theories of public sector organisational effectiveness and political control pay special attention to autonomy. The former typically emphasises autonomy's salutary operational qualities: it allows agencies to use their expertise to solve pressing implementation problems, make and execute decisions quickly, and pursue their missions in an administratively rational manner (see, e.g. Wilson 1989; Wolf 1993; Meier 1997; Rainey and Steinbauer 1999; Brewer and Selden 2000). These theories also assume that autonomy has motivational benefits at the employee level. Individuals particularly individuals with high levels of formal education and professional training - value autonomy and work harder when it is given to them (see, e.g. Gagné and Deci 2005). In contrast, theories of political control tend to view autonomy as necessary - bureaucracies have expertise that political actors lack, and so delegations of authority are sometimes unavoidable but potentially problematic, given that bureaucracies are nonelectoral institutions. Yet, even political theories note the importance of autonomy for organisational performance. Gailmard and Patty (2007, 2012), for

to exist between Congress and the bureaucracy (Miller 2005). In addition, Congress is hardly an agency's only boss (Whitford 2005; Gailmard 2009), yet we would argue that the existence of multiple principals actually attenuates the empirical results we find below.

4 That congressional oversight is primarily determined by political and policy motivations is well established in the political science literature (see, e.g. Dodd and Schott 1979; Aberbach 1990; Kriner and Schwartz 2008; Parker and Dull 2009; Kriner and Schickler 2013; McGrath 2013). 
example, argue that congressional principals, who generally prefer informed to uninformed policymaking, proactively grant autonomy and policymaking discretion to bureaucratic agents in order to incentivise investments in expertise. Whatever their differences, both schools tend to agree that autonomy is systematically associated with organisational performance and the development of policy expertise. Consequently, we believe it is important to examine whether congressional oversight is associated with agency autonomy.

\section{Congressional oversight and its managerial consequences}

We expect that congressional oversight will be negatively associated with autonomy and job satisfaction when such oversight is primarily meant to monitor and control the bureaucracy for political reasons, rather than to aid it in the performance of agency duties (Weingast and Moran 1983; Ferejohn and Shipan 1990; Shipan 2004). Congress is often unlike the manager or firm owner described in standard economic accounts of principal-agent theory. In these accounts, it is usually assumed that the principal is concerned with securing some outcome and is, moreover, happy to let the agent choose whatever means or behaviours best serve that end (for a review, see Eisenhardt 1989). The congressional impulse to control, however, often seeks to dictate the bureaucracy's choice of means. This impulse is intensified in our separation of powers system, where Congress often competes with the president for agency influence (Shapiro 1994; Whitford 2005). Below, we identify three particular mechanisms through which congressional oversight can harm agency morale and conclude by arguing that oversight's relationship with morale is ultimately conditional on whether it is adversarial or friendly.

\section{Mechanism I: micromanagement}

Consistent with the predilection of Congress to be interested in control rather than performance, scholars have long noted that its oversight relationship with the federal bureaucracy has been characterised by micromanagement, or "intervention by Congress in administrative details" (Gilmour and Halley 1994, 10). As early as 1885, Woodrow Wilson complained that Congress "has entered more and more into the details of the administration, until it has virtually taken into its own hands all the substantial powers of government" (Wilson 1896, cited in Beermann 2006). Similarly, Wilson wrote that "Congress is commonly criticized for 'micromanaging' government agencies; it does and it always has" $(1989,241)$. More recently, Behn identified political micromanagement as one of public 
administration's most pressing problems and elucidated how it hampers agency performance: "The legislative branch is, for some reason, unhappy with the way an executive-branch agency is performing; so the legislators impose some rules on the agency ... These new rules prevent, or at least constrain, the agency from doing what the legislature dislikes. Unfortunately, these rules also constrain the agency from producing the results for which it is responsible" $(1995,316)$.

There is reason to believe that oversight has become increasingly driven by this impulse to micromanage and constrain bureaucratic discretion. Summarising a series of 10 case studies on oversight, Gilmour and Halley concluded:

The cases show a "congressional co-manager" intervening directly in the details of policy development and management rather than enacting vague, wide-ranging, sweeping statutes to change fundamental policy directions ...

Gone almost without a trace is the post-New Deal Congress that optimistically delegated broad-scale public problems and policy questions for solution and resolution by the executive branch. Much diminished as well is an executive branch relied upon by Congress for neutral competence and specialized expertise. Instead, the story ... is one of the retrieval of executive discretion and the highly specific redefinition-by Congress-of prior delegations of authority. (1994, 335-336)

In the same vein, Aberbach (1990) showed that the average number of pages per statute enacted by Congress rose sharply between the 80th (1947-1948) and the 103rd (1993-1994) sessions of Congress, indicating an increased command-and-control orientation in legislative-bureaucratic relations. More recently, Balla and Deering (2013) coded a sample of all congressional hearings that occurred during the 96th (1979-1981), 100th (1987-1989), 104th (1995-1997) and 108th (2003-2004) sessions of Congress. They found that most hearings - over $80 \%$ in each session - are police patrols, as opposed to fire alarms, indicating that Congress has an abiding interest in monitoring what the federal bureaucracy is doing and in how it is doing it.

As a recent illustration of this mechanism, scholarly research and witness testimony from administrators from the Centers for Medicare and Medicaid Services (CMS) attest that members of Congress are keen to micromanage policies governing provider payment (Pham et al. 2009). The data that we compile below support these claims, indicating that there were no fewer than 377 oversight hearings from 1999 to 2013 where members of Congress expressed their views on this issue, often disagreeing 
with CMS policies. Representative of these interactions is a 15 May 2007 hearing of the House Committee on Ways and Means's Subcommittee on Health, under the direction of subcommittee chairman Pete Stark (D-CA). In this hearing, titled "Payments to Certain Medicaid Fee-for-Service Providers", Stark belies his intent to intervene in CMS regulations, upon "hearing from industry that many of these regulations, particularly the inpatient hospital regulations, are nothing but backdoor attempts to circumvent Congress and cut spending". In addition, despite being "loathe to intervene in the nuts and bolts of regulations", and generally thinking "that level of detail is best left to the experts like Mr. Kuhn [Herb Kuhn, then Acting Deputy Administrator, Centers for Medicare and Medicaid Services]", Congressman Stark felt impelled to give pages of suggestions on how CMS should direct fee-for-service payments to providers. Such intricate congressional involvement in agency decisions is common in our hearings data and an indication that more oversight often means more direct congressional involvement in policy implementation.

Micromanagement is fundamentally a psychological mechanism. It is harmful to agency morale because it politicises employees' work and, in doing so, undermines employees' ability to experience meaning while performing their jobs (Hackman and Oldham 1976; Ryan and Deci 2000; Barrick et al. 2013). A large body of research on "public service motivation" suggests that for many individuals who are employed in the public sector the experience of meaning flows from doing work that is thought to advance the public good (see, e.g. Perry and Wise 1990; Houston 2009). At its core, public service motivation is an "other-regarding" orientation; it entails a broad-based concern for the well-being of one's fellow citizens, as opposed to a more narrow concern for particularistic interests (Ward 2014). Micromanagement can hurt agency morale by appropriating an agency's collective work effort for partisan purposes and, in doing so, stripping that effort of its politically neutral public service meaning. Just as a generic manager's use of monetary rewards to incentivise employee effort can "crowd out", or displace, an employee's intrinsic motivation for doing a job well (Frey and Oberholzer-Gee 1997), congressional micromanagement can crowd out agency employees' public service motivation by signalling to employees that their work is ultimately partisan in nature.

We view congressional micromanagement as a variable that shapes an agency's shared understandings of, and collective beliefs about, the purpose of its core work. In other words, micromanagement affects agency morale via its influence on agency culture. In this view, an employee need not be directly exposed to congressional oversight for the micromanagement mechanism to be operative; the employee need only be exposed to the 
agency's prevailing cultural beliefs. In agencies that are subject to a significant amount of politically motivated oversight, we would expect a "politicised" culture to obtain. In these agencies, employees would understand their work to be primarily partisan and would be demoralised by this understanding. In contrast, in agencies subject to little political oversight, we would expect a relatively "apolitical" culture to obtain. In these agencies, employees would understand their work to be primarily in service of the public good and would be heartened by this understanding.

\section{Mechanism II: short term, recurring opportunity costs}

Besides this micromanagement mechanism, there are at least two more possible avenues by which oversight may harm agency morale. First, preparing for and participating in oversight hearings, especially high-profile ones, levies opportunity costs on agency employees. Rather than focussing on, say, fulfilling their missions, or competently implementing legislative policy, agency employees must respond to the priorities of a committee holding an oversight hearing. We call these opportunity costs short term to differentiate them from the more fundamental (and psychological) crowding-out of experienced meaning that congressional micromanagement entails.

Short-term opportunity costs likely fall most squarely on agency managers, especially those who are called to testify in an oversight hearing. These employees must, quite literally, put down whatever they are working on to prepare for and attend a hearing. A recent journalistic account of declining morale among high-level agency managers at the Department of Homeland Security supports this line of reasoning. As the article notes, "Many former and current officials said the most burdensome part of working for DHS is the demands of congressional oversight. More than 90 committees and subcommittees have some jurisdiction over DHS, nearly three times the number that oversee the Defense Department. Preparing for the blizzard of hearings and briefings, officials say, leaves them less time to do their jobs" (Markon et al. 2014).

While we assume that oversight hearings will produce higher opportunity costs for managerial than nonmanagerial employees, it is plausible that at least some of these costs will impinge on the daily work routines of an agency's middle- and lower-level employees. Managers will likely need help preparing for and responding to hearings, and it is reasonable to expect that they will delegate some of their hearings-related work to nonmanagers. Yet, in terms of their impact on the felt autonomy and job satisfaction of nonmanagerial employees, we view short-term opportunity costs as secondary to micromanagement. Although micromanagement undermines 
the very meaning of work done by agency employees, opportunity costs are merely temporary (albeit perhaps frequent) disruptions to an employee's work routine. ${ }^{5}$

\section{Mechanism III: public shaming}

Finally, it is reasonable to assume that negative congressional attention whose aim is to publicly embarrass high-level agency managers would be demoralising to the agency as a whole. A recent example of this involves the General Services Administration (GSA) and the attention it received in 2012, after stories of wasteful spending at its Western Regions Conference surfaced in the media. The aftermath included many high-profile oversight hearings and numerous internal reports that sought to assign responsibility for the agency's actions. As "fraud, waste and abuse" are anathema to both parties, Democrats as well as Republicans relentlessly attacked the GSA in hearings. In this instance, Congress can be seen to have had a genuine interest in improving GSA performance into the future. In other words, this was an ideal opportunity for Congress to act as a genuine performance manager - that is, to take a sincere interest in remedying whatever underlying organisational problems (e.g. issues with organisational culture, ineffective internal accountability structures, etc.) may have contributed to the GSA scandal. Instead, Congress appeared to be more interested in obtaining whatever political mileage it could by publicly scolding top-level GSA employees.

Of course, agency managers should be called to account for agency misbehaviour. Nevertheless, it is important to emphasise that public shaming is not viewed as a constructive managerial practice in the organisational behaviour and public management literatures. In fact, recent research suggests that "abusive supervision", which includes "nonphysical actions such as angry outbursts, public ridiculing, taking credit for subordinates' successes, and scapegoating subordinates", is negatively associated with job satisfaction, turnover intention and additional markers of employee morale (Tepper 2000, 2007; Aryee et al. 2007). ${ }^{6}$ Importantly, research in this vein also indicates that the abusive supervision endured by an organisation's higher-level employees "trickles down" to its lower-level employees

${ }^{5}$ We do not separate managers from nonmanagers in our empirical analyses below, as this would limit the number of agencies for which we had enough managers to calculate aggregate morale. If managers are more negatively influenced by congressional oversight than nonmanagers, the large presence of nonmanagers in our data would bias our coefficients downward, making our estimates conservative.

${ }^{6}$ In their account of declining morale at the Department of Homeland Security, Markon et al. (2014) identify "relentless congressional carping" as a source of employee unhappiness. 
(Aryee et al. 2007). In this view, the supervisory treatment that high-level employees receive influences the manner in which they treat their own subordinates. Notwithstanding these potential trickle-down effects, we assume that public shaming is more strongly associated with managerial employees' morale than nonmanagerial employees' morale. Although the high-level managerial employees who attend hearings will endure any shaming attempts firsthand, nonmanagerial employees' exposure will be indirect.

\section{"Advocacy" and the conditional effects of oversight}

Thus far, we have discussed three mechanisms via which oversight hearings may negatively affect agency morale. These mechanisms would seem to operate across qualitatively different types of oversight hearing. Police patrol oversight, for example, is most likely to reflect Congress's desire to micromanage (Balla and Deering 2013). These hearings also require diligent agency preparation and are likely to command persistent shortterm opportunity costs. Fire alarm hearings (McCubbins and Schwartz 1984) also require agency preparation, often on short notice, and thus we expect agencies to be burdened by high opportunity costs here as well. In addition, fire alarms are more likely to trigger particularly adversarial hearings, thus activating the public shaming mechanism. ${ }^{7}$ In fact, all of these mechanisms rely on the assumption that oversight hearings are contentious affairs.

Yet, existing work (Aberbach 1990) cautions us against making the assumption that all hearings serve the same purpose. Aberbach (1990), drawing on survey evidence from committee members and their staff, shows that much congressional oversight activity takes place in what he calls an "advocacy context". Aberbach stresses that there are two general types of committee oversight: adversarial hearings meant to score political points or forcibly change agency policy (through micromanagement, as discussed above); and advocacy hearings, where members of Congress defend "their" preferred programmes and agencies by holding hearings and officially voicing praise and approval. This type of oversight is qualitatively different from that assumed in our theoretical discussion regarding the negative effects of hearings on agency morale. There is little reason to expect any of the three proposed mechanisms to drive down morale when committees are friendly towards agencies in hearings. In fact, we might even

\footnotetext{
${ }^{7}$ In the empirical analyses that follow, we are largely agnostic as to the mechanism driving the findings, and suspect that all three are at work across the heterogeneous sample of hearings and agencies in our data set.
} 
expect that advocacy hearings increase agency morale, as they publicly demonstrate agency accomplishments, and can serve to justify increased appropriations (Aberbach 1990, Chapter 8). In addition, when Congress's and the bureaucracy's goals are aligned and oversight is positive and advocacy driven, it is conceivable that Congress might assume the salutary managerial role that is exalted in theories of public sector organisational effectiveness (O’Toole and Meier 1999; Rainey and Steinbauer 1999; Fernandez 2005; Lee and Whitford 2013).

We ultimately argue that the relationship between congressional oversight activity and agency morale is a conditional one. When oversight is politically driven and adversarial, we expect it to harm agency morale, for the reasons discussed above. Yet, when oversight is more "friendly", agencies can benefit, both tangibly and intangibly, from congressional attention. Although agencies still have to prepare for these hearings, the outcomes of these preparations (potential praise and material rewards) can often outweigh the short-term opportunity costs of hearing involvement. Thus, to the extent that oversight hearings are positive towards the target agency, we expect them to increase agency morale.

\section{Data, variables and methods}

In order to assess the conditional relationship between congressional oversight and agency morale, we first created empirical measures of each. We focussed exclusively on formal oversight hearings as, of the myriad forms of oversight, ${ }^{8}$ these are the most straightforward to quantify and have been the focus of many empirical studies (Dodd and Schott 1979; Aberbach 1990; Ogul and Rockman 1990; Smith 2003; Balla and Deering 2013; McGrath 2013; MacDonald and McGrath forthcoming). Nevertheless, existing studies have not considered oversight as an agency-level demandside variable, and have instead focussed almost entirely on the supply-side of oversight. The few studies that have considered oversight from an agency perspective have focussed on small samples of agencies or hearings and have not documented the overall extent to which agencies are called to appear before Congress (see, e.g. Parnell 1980; May et al. 2008, 2009, 2011).

${ }^{8}$ There are many ways in which legislatures can review, monitor and supervise executive action. Committee members may engage in personal communication (even when this communication is technically illegal as "ex parte" communication) with bureaucratic staff or agency heads. Committee staff may also engage in such casework on behalf of their constituents. Besides committees, inspectors general reports (Light 1993), General Accounting Office reports and resolutions of enquiry (Oleszek 2001) can serve to supplement the formal oversight work that committees engage in through hearings. 
Therefore, we developed a unique measure of oversight hearings directed at federal agencies as our primary independent variable.

\section{Oversight hearings data}

We collected data on oversight hearings from the Government Printing Office's Federal Digital System (GPO's FDsys) (http://www.gpo.gov/fdsys/ search/advanced/advsearchpage.action). ${ }^{9}$ The GPO began publishing a sizable number of hearing transcripts in 1997; therefore, we started our collection there. ${ }^{10}$ The description of the GPO's hearings data indicates that committees sometimes take up to two years to publish hearings, and thus we attenuated our data set to conclude at the end of $2011 .{ }^{11}$ We collected the universe of hearings by searching the "Congressional Hearings" database with an empty keyword field and saved each full-text transcript. Each transcript contains a list of witnesses called before Congress for the hearing, including their affiliation with federal agencies, when applicable. All told, we identified 17,572 hearings in these data. We parsed the text of each individual hearing transcript to create witness data and then narrowed the witnesses by whether or not they represented an agency. We considered a hearing to be directed at a particular agency only if the committee or

${ }^{9}$ Smith (2003), McGrath (2013) and MacDonald and McGrath (forthcoming) used hearings data from the Policy Agendas Project's (www.policyagendas.org) Congressional Hearings database (http://www.utexas.edu/cola/_webservices/policyagendas/ch/instances.csv?from=1945\&to=2012) to construct summaries of oversight activity. Designed to capture congressional behaviour, this data source fails to indicate any agency information for the identified hearings. That is, although one can measure how often each committee or subcommittee of Congress met with agency personnel in a formal hearing, the Policy Agendas Project does not allow us to recover which agency is being scrutinised in each hearing.

10 We found hearings from 1993 to 1996 in the FDsys, but these constitute far less than a universe of committee hearings in those years. In addition, we limit our sample by ignoring data from 1997 to 1999, as the number of hearings identified in the GPO data for those years is far fewer than the number recorded in the Policy Agendas Project data.

11 The GPO further reports (http://www.gpo.gov/fdsys/browse/collection.action?collection Code $=\mathrm{CHRG}$ ) that "Not all congressional hearings are available on FDsys. Whether or not a hearing is disseminated on FDsys depends on the committee. GPO continues to add hearings as they become available during each session of Congress. If a congressional hearing is not listed in FDsys, it is not available electronically via GPO at this time. NOTE: If a committee has not made a hearing available electronically via GPO for a specific Congress, the committee's name will not appear in the browse list until a hearing for that committee is made available in FDsys". Although this is a worrying disclosure, each standing committee with oversight jurisdiction published hearings through the GPO in all years of the data. In addition, as mentioned above, the hearings published via the GPO closely track those identified in the Policy Agendas Project from 1999 to 2004 (the end year of complete data in that data set). In short, missing hearings data may be a problem, but there is no way to confirm the extent to which it is, or to correct for such missing data. We are confident that we have collected the universe of publicly available hearings data from 1999 to 2011. 
subcommittee holding the hearing called a witness from that agency. There are often cases where there are no agency-affiliated witnesses for a given hearing and still others where an individual hearing applies to multiple, and sometimes many, agencies. Next, we attempted to identify hearings that were meant to conduct oversight and separate them from legislative hearings. As described in supplementary appendix A, we followed recent research (McGrath 2013; MacDonald and McGrath forthcoming) and filtered oversight hearings by searching the full-text transcripts for keywords that might indicate oversight. ${ }^{12}$ After filtering, we identified a total of 11,407 oversight hearings in our data.

Once we identified agency witnesses and separated oversight from nonoversight hearings, we grouped hearings by agency and year. The agencyyear data set then had 1,053 observations - 13 full years of data for 80 agencies and two agencies with fewer than 13 observations because of being created after 1999. ${ }^{13}$ The agencies were grouped by the coding scheme for the 2012 Federal Human Capital Survey so as to allow us to match the hearings data to the agency morale data described below. Generally speaking, the data are grouped at the department level, including independent agencies and the Office of Management and Budget (part of the Executive Office of the President), with some departmental subunits included. ${ }^{14}$

Supplementary Table A1 (appendix A) indicates each agency for which we have collected hearings data and gives descriptive statistics for such oversight activity. Figure 1 displays how the total number of oversight hearings committees held across the 82 coded agencies varies over time. The data cover a time period that was characterised by the full diversity of institutional and partisan configurations - namely, we have been through unified government, divided government with a unified Congress, divided government with a divided Congress, Republican presidents, Democratic presidents and changes in the partisan control of each chamber during this period. Figure 2 displays temporal changes in oversight hearings across the 15 cabinet-level departments, further demonstrating the variation that exists in these data. In addition, Figure 3 shows, via box plots, the distributions of oversight hearings for each department. Although obviously crucial for testing how oversight can affect agency morale, these data are inherently interesting in demonstrating the significant variation that exists in how often certain agencies are called to appear before

12 These keywords are as follows: "oversight", "investigation" and "budget request".

${ }^{13}$ For this article, we focus on subsets of these agencies where data on agency morale are currently available, as described below and further in supplementary appendix A.

${ }^{14}$ For example, the US Air Force, Army and Navy are treated discretely apart from their parent Department of Defense. 


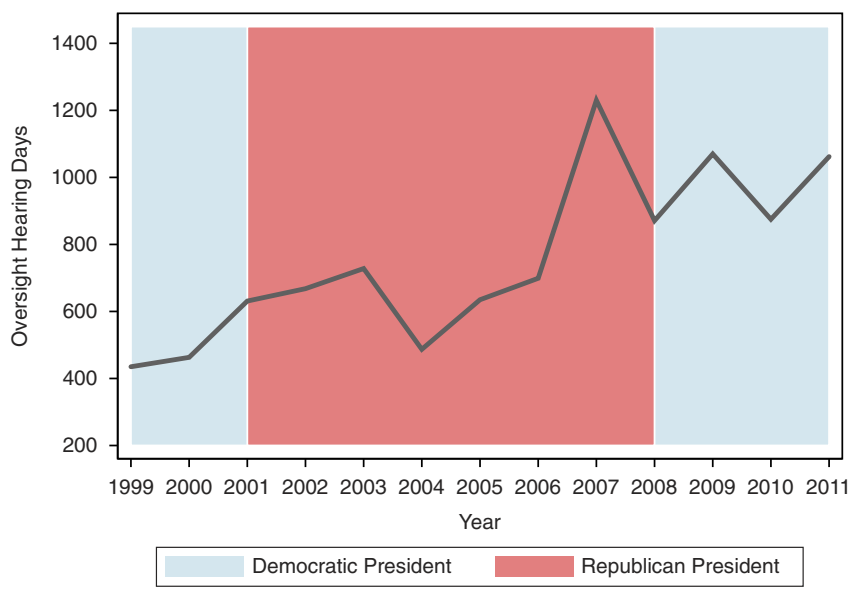

Figure 1 Oversight hearing days (1999-2011)

Note: Figure created by summing all oversight hearing days for all agencies in a given year. Hearings can involve more than one agency at a time, so this can result in double-counting hearings. We show this double-counted measure of hearings activity as it more accurately captures total agency attention to congressional priorities.

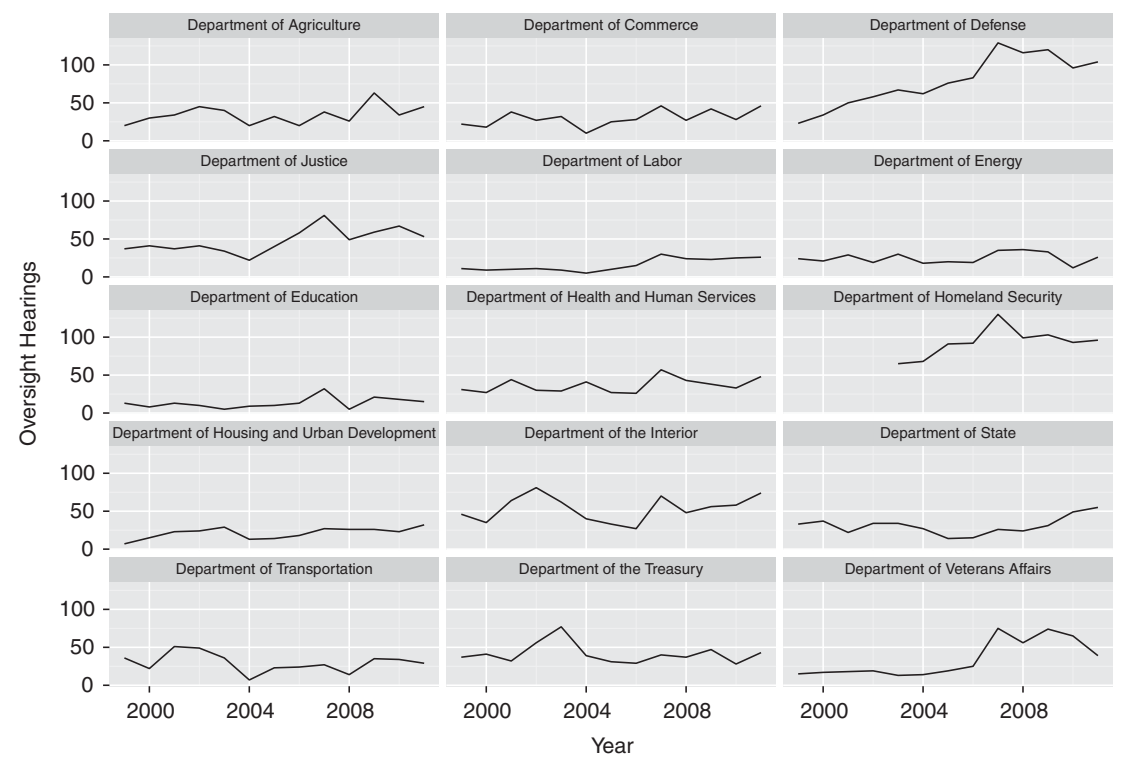

Figure 2 Oversight hearings over time by department 


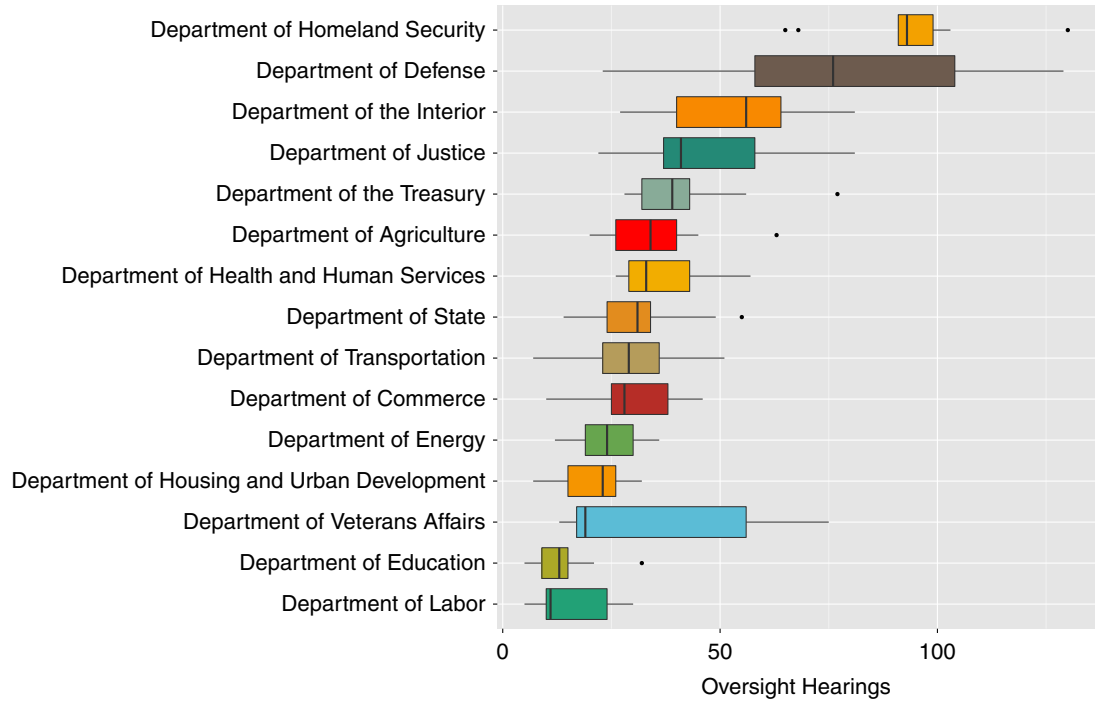

Figure 3 Distribution of oversight hearings by department

Note: Horizontal lines give the median for each agency, boxes give the bounds of the interquartile range and dots show outliers.

Congress, and future research should model this variation as an outcome, as well as a determinant of agency characteristics (MacDonald and McGrath forthcoming).

\section{Measuring hearing sentiment}

As we have argued above, the effects of oversight on morale should depend on the fundamental tone and purpose of the hearings. As such, we additionally analysed the content of each hearing to categorise it as either adversarial or advocacy driven. Adversarial hearings reflect what most observers think of when they consider oversight. Here, members of congressional committees call agencies to task for poor performance, or simply for implementing policy inimical to the wishes of a committee. These hearings are often acerbic affairs, and are unpleasant experiences for agency employees called to testify. They additionally require agencies to prepare extensive reports and testimony to avoid public embarrassment. These are the hearings that we expect to negatively affect agency morale.

On the other hand, Aberbach described an alternative to adversarial hearings: "While one's first reaction to the word 'oversight' is that Congress is at odds with an agency or program targeted, committees sometimes use oversight because they want to defend 'their' program or agency against 
others who would do it harm" $(1990,118)$. This brand of advocacy oversight has been largely overlooked by empirical studies, although there is evidence that this makes up a good part of Congress's oversight agenda, especially during unified government (see Aberbach 1990, Chapter 8). We do not expect such hearings to negatively affect agency morale; rather, we expect that when hearings are positive in tone, they will actually improve agency morale.

We thus seek to categorise congressional oversight as either adversarial or friendly, and we do so by measuring hearing sentiment. Specifically, we undertake computer-assisted sentiment analyses of each hearing, following standard practice in the computer science literature and a growing trend in the social sciences. ${ }^{15}$ Hearing transcripts follow a fairly standard format. They open with metadata about the hearing (those in attendance, the time and location of the meeting, a list of witnesses, etc.), and then invariably commence with the opening statements of the committee or subcommittee chair and other interested members of Congress. These opening statements are the primary source of our sentiment data, as they provide many instances where a member of Congress expresses sentiment towards an agency.

For each observation in the agency-hearing data set described above and in supplementary appendix A, we calculated a Targeted Sentiment score that we used to measure how positive (positive values to 1) or negative (negative values to -1 ) each hearing is with respect to the agency at hand. ${ }^{16}$ There is a good deal of variation in sentiment scores across the data, with a mean score of 0.068 and a SD of 0.278 (empirical range: -0.901 to 0.925 ). As our data are organised at the agency-year level, we aggregated from individual hearings by taking the mean sentiment for each agency and year (Hearings Sentiment). We assessed our conditional hypotheses below by interacting this overall measure of oversight sentiment with the total volume of oversight hearings conducted involving each agency in each year.

\section{Measuring agency morale}

Viewing agency morale as a set of characteristics best discerned from individual responses to surveys of federal employees, we adopted the

15 See, e.g. Hopkins and King (2010) and Grimmer and Stewart (2013) for overviews and applications for political science. The basic idea is that articles, tweets, posts, hearings, etc. express positive, negative or neutral sentiments and that we can uncover and estimate these sentiments using statistical models.

${ }^{16}$ As opposed to calculating the sentiment of the entire hearing, our scores measure sentiment directed towards a particular agency, denoted by the presence of the agency's name in each transcript. We use a general algorithm to calculate sentiment scores and describe our process and the algorithm in more detail in supplementary appendix B. 
approach of Bertelli et al. (2015) of measuring agency-level characteristics by aggregating these individual responses. This approach builds on earlier attempts to use individual employee attitudes to approximate unobservable agency characteristics, ${ }^{17}$ and seeks to overcome some of the limitations of these types of data. In particular, Bertelli et al. (2015) provided a framework for aggregating survey responses in such a way as to put agency-level summaries on a common scale for cross-agency and overtime comparisons. Such an approach is key for our endeavour to test the effects of oversight activity on agency morale in a panel data setup. Having consecutive years of data on oversight and agency morale across agencies thus allows us to use a fixed effects design, isolating the within-agency effects of changes in oversight activity on self-reported agency characteristics.

Bertelli et al. (2015) started by identifying the agency characteristics they wished to measure: autonomy, job satisfaction and intrinsic motivation. They considered these characteristics to be latent attributes and used individual responses to particular questions from federal personnel surveys to measure these constructs using a dynamic Bayesian item-response model similar to the approach in Martin and Quinn (2002) (see also, Clinton et al. 2004, 2012; Bertelli and Grose 2011). ${ }^{18}$

Of these measured agency-level characteristics, we focussed particularly on agency autonomy and job satisfaction as constructs that relate to agency "morale" as a meta-characteristic of interest. Bertelli et al. (2015), among other studies, did not necessarily equate autonomy with the possession of objectively large amounts of statutory administrative discretion (Epstein and O'Halloran 1999; Huber and Shipan 2002). Instead, autonomy refers to the extent to which bureaucrats feel in control of their own surroundings in performing their duties: a more subjective sense of discretion. The job satisfaction variable is what organisational behaviour researchers typically call a "global" measure - that is, a measure of overall job satisfaction. Each of the three survey items that together constitute this measure encourage respondents to think in very broad terms about their jobs. One of the items asks, for instance, "Considering everything, how satisfied are you with your job?". ${ }^{19}$

17 See Bertelli et al. (2015) for a brief review of these studies.

${ }^{18}$ See supplementary appendix $\mathrm{C}$ for a description of these data sources and a list of the questions and the surveys from which they were drawn. For more information on the aggregation and estimation procedures, see Bertelli et al. (2015).

${ }^{19}$ In contrast, "facet" measures of job satisfaction are comprised of survey items that refer to specific aspects of an individual's job, such as satisfaction with one's coworkers, satisfaction with one's opportunities for career advancement or satisfaction with one's pay. We use a global measure of job satisfaction because meta-analytic evidence suggests that global measures are stronger predictors of job performance than are facet measures (see Judge et al. 2001). 

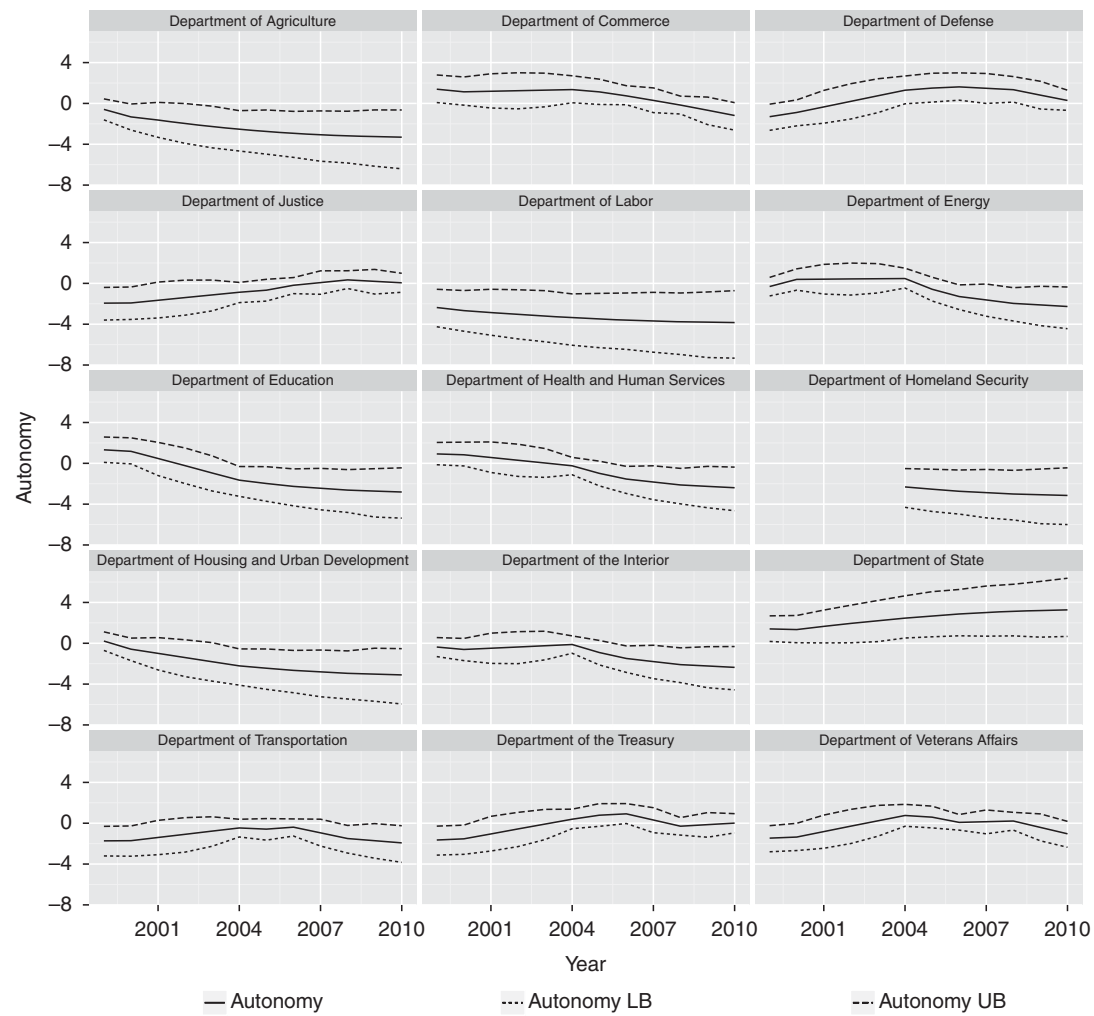

Figure 4 Agency autonomy by department

Figure 4 displays the autonomy measures and the variation that exists in each across the cabinet departments, as Figure 5 does for the measure of job satisfaction. ${ }^{20}$

\section{Empirical strategy}

Having collected panel data ${ }^{21}$ on levels of oversight and agency morale characteristics, with each measure varying considerably over time (again, see Figure 2, 4 and 5), we turn now to identifying the most appropriate empirical design by which to assess the relationship between oversight

${ }^{20}$ These are the summary measures found at http://agencydata.wordpress.com. They are bounded at -5 and 5 .

${ }^{21}$ The panel is unbalanced, as some agencies are missing data on key variables in some years. See supplementary appendices A and C for more information regarding missingness in the data. 


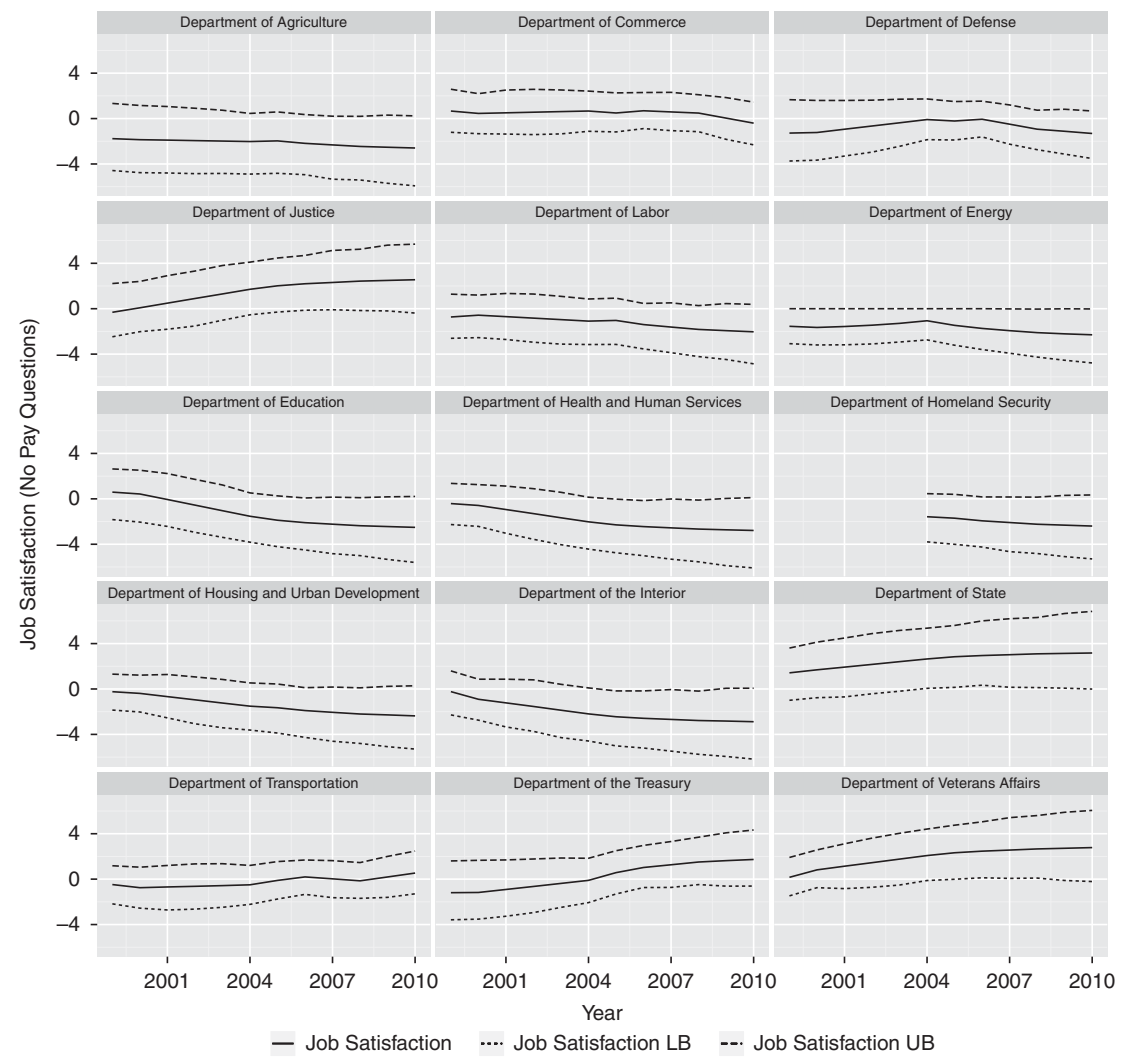

Figure 5 Job satisfaction by department

and morale. We are primarily interested in the effect that changes in oversight might have on agency morale over time. Ideally, we would like to tease out temporally causal relationships from confounded, spurious or endogenous correlations and have chosen a design and model specifications that we believe will help us get there. In particular, we take advantage of our data structure to estimate fixed effects models, thus accounting for unobserved agency heterogeneity and isolating the effects of time-varying covariates on time-varying agency characteristics.

Yet, this design does not erase the potential for biased estimates, nor does it guarantee casual interpretations of these estimates. In particular, we are careful to measure and account for factors that might simultaneously cause increases in oversight activity and changes in autonomy and job satisfaction, respectively. Our primary explanatory variable, Oversight Hearings, varies both across and within agencies over time, and our 
research is designed to isolate the effects of within-agency across-time changes in oversight on expressed agency traits. Therefore, we limited our attention to control variables that similarly vary within agencies over time, as the fixed effects eliminate all sources of time-invariant agency heterogeneity, observed and unobservable.

News sentiment and other controls. Perhaps, most importantly, we controlled for the possibility that something, such as an agency scandal of the sort described above with respect to the GSA, contributes both to the variation in Oversight Hearings and to the measures of agency morale. Agency scandals and aggregations of smaller issues related to poor agency performance invariably lead to "fire alarm" oversight by congressional committees eager to show constituents how they can fix agency problems (McCubbins and Schwartz 1984). Scandals and poor performance also generate negative media attention that presumably has deleterious effects on agency morale, independent of the potential effects of the hearings themselves. It is thus necessary to disentangle the effects of negative media attention from the effects of congressional oversight. ${ }^{22}$

To this end, we created a measure of media attention by collecting all stories published in the Washington Post that mentioned each agency in our data set. ${ }^{23}$ We grouped the stories by agency and year and calculated the total number of stories and pages of coverage. This approach is similar to recent attempts to measure mass media attention to federal agencies (Lee et al. 2009; Lee and Whitford 2013), but we must also take into account the sentiment that these aggregated stories reflect towards agencies. Therefore, exactly as we did with the hearing transcripts, we measured the targeted sentiment of each news article in these data to create News Sentiment scores reflecting how positive (positive values to 1 ) or negative (negative values to -1 ) each piece of coverage is with respect to the agency at hand. We then calculated the sum of News Sentiment scores for each agency-year and used this as our measure, Total Washington Post Sentiment, capturing both the amount and direction of news coverage of the agencies in our data.

${ }^{22}$ Fire alarms may also spur court action, as federal courts have vast jurisdiction over federal agency policymaking and have the power to overturn agency decisions. Such court action might simultaneously affect agency morale and drive oversight activity, and, although it would be best if future research could directly measure and incorporate judicial attention, we rely on the likely correlation of such attention with the media attention variable we create below to assuage our concern that is a threat to inference.

${ }^{23}$ We accessed the stories using the Lexis Nexis Academic database. We chose to explore Washington Post stories, in particular, because this newspaper dedicates more of its coverage to the federal bureaucracy than other national news organisations such as the New York Times. See supplementary appendix D for more detailed coding information. 
We also accounted for political attention to agencies, apart from the attention that oversight hearings themselves indicate. First, we separately included the volume of Nonoversight Hearings for each agency-year into our models. These are the hearings that we collected from the GPO that did not include the keywords we considered to indicate oversight. ${ }^{24}$ Likewise, we recognised that agencies may be the recipients of other kinds of political attention that may affect employees' responses to survey questions. As in the study by Lee and Whitford (2013), we operationalised a Presidential Attention variable, using the GPO's FDsys to search for mentions of each agency in the Public Papers of the Presidents of the United States. ${ }^{25}$ Whitford (2013) argued specifically that presidential attention might signal that political resources (time and money) are available for agency policy priorities.

In addition to these measures of media and political attention, we included indicators for various regimes of political control. Although we are mostly agnostic about the potential effects of these variables on changes in agency morale, we know that they are important determinants of congressional delegation to agencies in the first place (see, e.g. Kiewiet and McCubbins 1991; Epstein and O'Halloran 1996; Huber and Shipan 2002; Volden 2002) and of congressional incentives to hold hearings with or investigate agencies (see, e.g. Mayhew 2005; Kriner and Schwartz 2008; Parker and Dull 2009; McGrath 2013). These variables include an indicator for Divided Government, and one each for Republican Control of Congress, Democratic President and Presidential Transition Year.

Notably, we did not include any time-invariant agency characteristics, as they would present identification issues in a fixed effects setup. This ultimately means that we cannot directly assess which specific mechanisms are at play in generating the relationships that we find. Although these mechanisms have distinct observable implications, these are found in agency-level characteristics and unmeasured characteristics of the hearings. For example, we argued above that public shaming can cascade from those managers who were involved in an oversight hearing to agency careerists. This mechanism might imply that such cascades should have larger impacts on agency morale in small, tight-knit agencies. Yet, agency size is largely

\footnotetext{
${ }^{24}$ The bulk of these nonoversight hearings concern prospective legislation, where agency testimony is used by a congressional committee to inform their policy decisions.

$25 \mathrm{http}: / /$ www.gpo.gov/fdsys/search/advanced/advsearchpage.action. We did the same with the Congressional Record for a measure of Congressional Attention, apart from attention through hearings. Yet, with agency fixed effects, we are limited in the number of covariates that we can include in a single model and this variable proved highly correlated (Pearson's $r$ of 0.67) with our measure of Oversight Hearings.
} 
time-invariant, and is thus collinear with agency fixed effects. ${ }^{26}$ Indeed, these agency fixed effects are crucial for us to make reliable estimates of the relationships between oversight and morale, as agency characteristics (e.g. size, budget, political insulation) are so often correlated with each other and with congressional attention. We thus limit our current attention to uncovering reliable estimates, net of the effects of agency-level characteristics, and leave the subtle task of mechanism assessment to future research. ${ }^{27}$

We should also note that we have some ex ante concerns regarding endogeneity. Specifically, it might be the case that instead of oversight activity affecting agency morale, the relationship is the inverse, with congressional committees choosing to hold hearings with agencies with particular latent characteristics, such as high or low autonomy. We took a number of steps to ameliorate this inferential pitfall. First, we lagged the hearings covariates by one year. There is little reason to expect a contemporaneous and swift reaction in the autonomy or job satisfaction dependent variables to a change in hearings activity. Instead, by lagging each of the hearings variables, we can assess what we see as a more realistic temporal ordering, where the effects of hearings in period $t-1$ take until the survey in period $t$ to be reflected in the measured agency traits. ${ }^{28} \mathrm{Next}$, we have specified each dependent variable as the one-time period change in agency autonomy and job satisfaction from time $t-1$ to time $t$. As plausible as it is to consider oversight and morale being endogenously related, it is less worrisome to consider the unlikely scenario that Congress oversees agencies with especially high (or low) changes from year to year in autonomy (or job satisfaction). For these reasons, we have both lagged the primarily important hearings independent variables and created differenced change in autonomy and job satisfaction dependent variables.

In addition, we have modelled remaining endogeneity directly with an instrumental variables approach (see, e.g. Angrist and Krueger 2001; Wooldridge 2010). Generally, for instrumental variables regression to solve endogeneity problems, one must find an IV that is strongly correlated with the endogenous regressor (Oversight Hearings), but not directly related to the outcome variable (Agency Autonomy/Job Satisfaction). We have

${ }^{26}$ We have included some slowly changing agency-level variables such as agency size, budget and percentage of employees who are appointed, but they do not add to model fit or change the substantive interpretations we present.

${ }^{27}$ Our data are not particularly amenable to testing mechanisms, so future research should focus on establishing the microfoundations of our theory by examining individual survey data, rather than aggregating to the agency level.

${ }^{28}$ We lagged the Total Washington Post Sentiment and Hearings Sentiment variables for the same reasons. 
identified two such instruments, Second Session of a Congress and Presidential Election Year, both of which drive down congressional oversight, but show no direct correlation with our dependent variables. Inclusion of these instruments and estimation of two-stage least squares regression does not change any of our substantive interpretations, lessening our concerns regarding endogeneity. ${ }^{29}$

\section{Results}

Table 1 displays results for both dependent variables. For each column, we have included all of the control variables described above, as well as agency fixed effects, and additional fixed effects for each year in the time series to account for systematic heterogeneity across time. ${ }^{30}$

In columns 1 and 2, we purposefully begin with a naive model specification. In these columns, we exclude information regarding hearing sentiment and assess the unconditional relationships between Oversight Hearings and the Change in Autonomy and Change in Job Satisfaction dependent variables. Estimating this unconditional relationship serves to highlight the importance of the models found in columns 3 and 4, where we empirically distinguish between adversarial and more friendly oversight. These unconditional results demonstrate that increases in lagged Oversight Hearings are associated with decreases in both autonomy and job satisfaction. Both of these effects are statistically distinguishable from 0 and are relatively substantial in their magnitude. In contrast, only one of the control variables across these first two models is statistically significant (Nonoversight Hearings in column 2).

Columns 3 and 4 introduce our operationalisation of the conditionality implied by theory. Although the results from columns 1 and 2 indicate that increased oversight activity leads to decreased agency autonomy and job satisfaction, we suspect that this is the case due to the distributions of adversarial and advocacy oversight hearings, with the former more likely to occur than the latter in the time period being studied. To assess this explanation, and to evaluate how oversight's effect on agency morale depends on the content of the oversight attention it receives, we included our measure of Hearings Sentiment. As described above and in supplementary

${ }^{29}$ For ease of interpretation, and as the results are largely identical across specifications, we present the standard regression results below, but present the second-stage instrumental variables results in supplementary appendix table E1.

${ }^{30}$ We also cluster all standard errors by agency to allow for agency-specific trends in the error term. This has the effect of increasing the standard errors and makes finding statistical significance more difficult. 
Table 1. Ordinary least squares models of agency autonomy and job satisfaction (1999-2011)

\begin{tabular}{|c|c|c|c|c|}
\hline & $(1)$ & $(2)$ & (3) & $(4)$ \\
\hline & Autonomy $\Delta$ & Satisfaction $\Delta$ & Autonomy $\Delta$ & Satisfaction $\Delta$ \\
\hline Oversight Hearings (lag) & $-0.00260(0.00146)^{*}$ & $-0.00195(0.00091)^{* *}$ & $-0.00252(0.00145)^{*}$ & $-0.00191(0.00091)^{* *}$ \\
\hline Hearings Sentiment (lagged mean) & & & $-0.53547(0.32041)^{*}$ & $-0.20647(0.20086)$ \\
\hline $\begin{array}{l}\text { Oversight Hearings }(\mathrm{lag}) \times \text { Hearings Sentiment } \\
\quad(\text { lagged mean })\end{array}$ & & & $0.01634(0.00579) * * *$ & $0.00877(0.00363)^{* * * *}$ \\
\hline Divided Government & $0.05127(0.04974)$ & $0.01691(0.03100)$ & $0.03571(0.04960)$ & $0.01032(0.03109)$ \\
\hline Republican Control of Congress & $0.06938(0.05048)$ & $0.01750(0.03145)$ & $0.07672(0.05008)$ & $0.02118(0.03140)$ \\
\hline Democratic President & $-0.06628(0.04879)$ & $-0.02864(0.03040)$ & $-0.05459(0.04856)$ & $-0.02286(0.03044)$ \\
\hline Presidential Transition Year & $0.01378(0.07490)$ & $-0.01149(0.04667)$ & $0.03486(0.07470)$ & $-0.00108(0.04683)$ \\
\hline Presidential Attention & $-0.00032(0.00122)$ & $0.00071(0.00076)$ & $-0.00025(0.00120)$ & $0.00075(0.00076)$ \\
\hline Nonoversight Hearings (lag) & $0.01320(0.00541)^{* *}$ & $-0.00062(0.00337)$ & $0.01294(0.00535)^{* * *}$ & $-0.00074(0.00336)$ \\
\hline Total Washington Post Sentiment (lag) & $-0.00001(0.00028)$ & $0.00005(0.00017)$ & $-0.00011(0.00028)$ & $0.00001(0.00017)$ \\
\hline Constant & $0.02891(0.20208)$ & $0.06925(0.12592)$ & $-0.06920(0.20863)$ & $0.01794(0.13079)$ \\
\hline Agency FE & Yes & Yes & Yes & Yes \\
\hline Year FE & Yes & Yes & Yes & Yes \\
\hline Observations & 470 & 470 & 470 & 470 \\
\hline$R^{2}$ & 0.543 & 0.676 & 0.555 & 0.680 \\
\hline AIC & 126.855 & -317.777 & 118.732 & -320.221 \\
\hline BIC & 475.685 & 31.052 & 475.867 & 36.914 \\
\hline
\end{tabular}

Note: Entries are linear regression coefficient estimates and standard errors, clustered by agency. The dependent variables are created by calculating the change in the Bertelli et al. (2015) measures of autonomy and job satisfaction (excluding compensation questions) from time $t-1$ to time $t$. Agency and year fixed effects (FE) are included in all models but not reported. See supplementary appendix A for further description of the oversight data, supplementary appendix $C$ for more information on the hearings sentiment scores and supplementary appendix D for a description of the Washington Post sentiment scores.

$\mathrm{AIC}=$ Akaike's information criterion; BIC $=$ Bayesian information criterion.

* $\mathrm{p}<0.10, * \mathrm{p}<0.05, * * \mathrm{p}<0.01$. 
appendix B, we measured a sentiment score [ranging from most negative $(-1)$ to most positive $(+1)$ ] for each agency hearing in the data. We then calculated the mean values of all of the hearings involving an agency as a global approximation of how negatively or positively Congress has interacted with each agency in each year (the mean of this variable for the estimation sample is 0.03 , with a SD of 0.15 and an empirical range from -0.52 to 0.84). We then interacted the lagged values of this hearings sentiment measure with the lagged number of Oversight Hearings involving each agency in each year to capture the intensity, as well as the direction, of agency-congressional interactions.

Column 3 presents results for Change in Autonomy when we added the interaction of Oversight Hearings and Hearings Sentiment to the specification from column 1. Here, the constitutive term for Oversight Hearings tells us that the effect of additional oversight hearings when the mean sentiment of hearings towards an agency are neutral (sentiment score of 0 ) is negative and statistically significant. Alternatively, we can approximately interpret this as meaning that the marginal effect of additional neutral oversight hearings is significantly negative, indicating that at least one of the mechanisms discussed above is at work even when hearings are not expressly negative in tone. The interaction term, on the other hand, indicates that as hearings become more positive, the effect of oversight on autonomy reverses and becomes statistically significantly positive at a Hearings Sentiment score around 0.50 . These very positive hearings likely constitute what Aberbach calls "advocacy" oversight, and when agencies see more of this type of oversight it tends to increase feelings of autonomy. As such extremely positive hearings are relatively rare in the data, this conditional relationship is obscured when we look at the results from columns 1 and 2. On the other hand, the results demonstrate that extremely negative hearings are even more likely to reduce agency autonomy than neutral hearings. To illustrate, the marginal effect of increases in hearing activity for neutral hearings (sentiment score of 0 ) is -0.002 , which more than triples for more negative hearings (sentiment score of -0.25 has a marginal effect of -0.007 ) and increases all the way to -0.011 for the most negative hearings in the data (sentiment score of -0.52). Thus, we have evidence that feelings of agency autonomy respond not only to the volume of activity but also to the degree of negativity (or positivity) they express.

These results are substantively meaningful. Consider the distribution of the Change in Autonomy dependent variable - mean: -0.0085, SD: 0.34 and range: -1.05 to 0.925 . When hearings are commonly negative (say, a standard deviation below the mean of Hearings Sentiment: a sentiment score of -0.12), it would take about 80 such hearings to lead to a standard deviation decrease in agency autonomy. On the other hand, if these 
hearings each carried a strongly positive sentiment (say, a sentiment score of 0.50 ), these 80 hearings would lead to an increase in agency autonomy of 0.045 , which is significantly larger than the variable's standard deviation. Although large increases in oversight are relatively rare (see Figure 2 and supplementary table A1 for more information on the distribution of the variable across agencies and over time), certain agencies $d o$ see relatively large changes in oversight over time. The Department of Defense, for example, increases from a minimum of 23 to a maximum of 129 in the data. In addition, focussing solely on the coefficient estimates and their marginal effects alone may obscure the importance of oversight. A change in oversight may lead to only a small change in autonomy, but that shifts the baseline for the next period, where more oversight can further decrease (or increase, if the tone of the hearings are positive) autonomy. The dynamics of the oversight-autonomy relationship thus allows us to treat the one period effect as a floor for the true substantive impact of oversight activity.

In Table 1, column 4 displays results for the same specification just described, but this time for the Change in Job Satisfaction dependent variable. Here, we see the same pattern of results as in column 4. Specifically, neutral and adversarial hearings tend to decrease aggregate (overall) job satisfaction within an agency, whereas more friendly hearings engender increases in such job satisfaction. Despite the statistical significance of the coefficient on the interaction term, the marginal effect for increases in friendly oversight is only marginally statistically significant, and only for the most positive hearings (sentiment scores of 0.65 or greater; compared with a 0.50 threshold for the Change in Autonomy dependent variable). Despite the smaller coefficients and effect magnitudes, we can make similar substantive interpretations of these results, as Change in Job Satisfaction has a smaller standard deviation (0.25) than does Change in Autonomy (0.45). In addition, across columns 3 and 4, the oversight and sentiment variables are the only factors that consistently affect agency measures of morale, suggesting that future studies of the determinants of morale, especially those using the Bertelli et al. (2015) approach, should at least control for oversight in their empirical models.

\section{Conclusion}

As a manager of the federal bureaucracy, Congress gets mixed reviews. On one hand, when it engages in friendly oversight, it bolsters agency morale. On the other, when it engages in adversarial oversight, it undermines agency morale. Some of the time, then, it appears to assume the salutary managerial role that is exalted in theories of public sector organisational effectiveness (O’Toole and Meier 1999; Rainey and Steinbauer 1999; 
Fernandez 2005; Lee and Whitford 2013). At other times, it appears to be more interested in micromanaging and publicly shaming agencies than in abetting their performance. Although it is of course Congress's prerogative to oversee the federal bureaucracy in the manner of its choosing, our results suggest that its interactions with agencies have concrete consequences for employee motivation. It strikes us reasonable that Congress should at least consider these consequences as it exercises its oversight function.

Quite simply, there is a balancing act that Congress should perform when considering oversight, and to truly understand it scholars need to assess the managerial consequences of oversight as well as its causes. Oversight may indeed be an effective mechanism for ensuring that agencies are responsive to the policy preferences of committee majorities (Kriner and Schickler 2013; McGrath 2013; MacDonald and McGrath forthcoming), but the congressional desire to monitor and control the bureaucracy should be balanced against adversarial oversight's likely detrimental effects on agency morale and, ultimately, agency performance. Our results suggest that "micromanagement" is more than a mere theoretical possibility. Apart from losing the benefits of delegation (expertise, insulation, etc.), Congress risks harming agency morale when it too vigorously monitors its agents. This should especially be concerning for a particular flavour of "show-horse" oversight that lacks policy content and is instead motivated by the desire to embarrass political opponents. Yet, it is also problematic in policy areas where technical expertise is required and political incentives align to meddle with policy details, as in the Medicare example above. ${ }^{31}$

Ours is the first study to examine the relationship between oversight activity and latent agency characteristics, but it should not be considered the last word on the topic. We admit to a number of specific drawbacks of this study, as currently constructed. First, we do not directly measure agency performance. Instead, we focus on publicly available data on agency autonomy and job satisfaction as precursors to performance. Second, although we have proposed three theoretical mechanisms via which adversarial oversight negatively affects agency morale, our analyses cannot distinguish between these mechanisms. We envision progress on this front occurring as existing approaches to textual analysis are refined. Ultimately, we hope to be able to distinguish adversarial oversight hearings in which Congress is micromanaging from adversarial hearings in which

${ }^{31}$ In fact, Congress itself has recognised the problem with this type of micromanagement and has sought to remedy its own proclivities. To wit, the 2010 Patient Protection and Affordable Care Act created an Independent Payment Advisory Board that has the ability to change payment schedules without previous congressional approval (although these decisions are subject to a supermajoritarian congressional veto). 
Congress is simply shaming an agency. At the same time, we hope to be able to distinguish friendly oversight hearings in which Congress is genuinely engaged in the role of a performance manager from friendly hearings in which Congress is simply patting an agency on the back. When genuinely engaged, we would expect Congress to express commitment to a clear mission, to be attentive to agency exigencies, to allocate resources when necessary and to buffer agencies from the demands of the external environment (e.g. from the demands of particularistic interest groups). Knowing with a greater degree of precision what sort of oversight is actually happening during a hearing will allow scholars to pin down the theoretical mechanism (or mechanisms) via which oversight operates on agency attitudes and behaviour.

Up to now, empirical research has largely ignored the potential managerial consequences, both positive and negative, of congressional oversight. In particular, oversight's negative managerial consequences have long been a cause for concern in the public administration and management literatures. At the same time, the political science literature evinces a deep concern for democratic accountability and its theoretical guarantor - political control. We have sought to synthesise these two perspectives and feel that we have identified an area where more research could lead to better agency performance on the ground. Our research speaks to classic debates concerning the politics-administration dichotomy and identifies a tangible consequence of the increase in oversight activity that has recently attracted much attention. Yet, a great deal remains to be done regarding empirical assessments of the consequences of congressional oversight.

\section{Acknowledgements}

A previous version of this paper was presented at the 2014 Annual Meeting of the Midwest Political Science Association, 3-6 April 2014, Chicago, IL. The authors thank Christopher Michael Carrigan, George Krause and numerous workshop participants from George Mason University's School of Policy, Government and International Affairs for providing useful feedback. The authors also thank Henry Siegel, Lauren Gallagher, Fatima Arif, Betsy Cliff and Erica Liao for research assistance on this project.

\section{Supplementary material}

To view supplementary material for this article, please visit http://dx.doi.org/ 10.1017/S0143814X15000367 


\section{References}

Aberbach J. D. (1990) Keeping a Watchful Eye: The Politics of Congressional Oversight. Washington, DC: Brookings Institution Press.

Angrist J. D. and Krueger A. B. (2001) Instrumental Variables and the Search for Identification: From Supply and Demand to Natural Experiments. The Journal of Economic Perspectives 15(4): 69-85.

Aryee S., Chen Z. X., Sun L.-Y. and Debrah Y. A. (2007) Antecedents and Outcomes of Abusive Supervision: Test of a Trickle-Down Model. Journal of Applied Psychology 92(1): 191-201.

Balla S. J. (1998) Administrative Procedures and Political Control of the Bureaucracy. The American Political Science Review 92(3): 663-673.

Balla S. J. and Deering C. J. (2013) Police Patrol and Fire Alarms: An Empirical Examination of the Legislative Preference for Oversight. Congress \& the Presidency 40(1): 27-40.

Barrick M. R., Mount M. K. and Li N. (2013) The Theory of Purposeful Work Behavior: The Role of Personality, Higher-Order Goals, and Job Characteristics. Academy of Management Review 38(1): 132-153.

Beermann J. M. (2006) Congressional Administration. San Diego Law Review 43(1): 61-159.

Behn R. D. (1995) The Big Questions of Public Management. Public Administration Review 55(4): 313-324.

Bendor J., Taylor S. and Van Gaalen R. (1985) Bureaucratic Expertise Versus Legislative Authority: A Model of Deception and Monitoring in Budgeting. American Political Science Review 79(4): 1041-1060.

Bertelli A. M. and Grose C. R. (2011) The Lengthened Shadow of Another Institution: Ideal Point Estimates for the Executive Branch and Congress. American Journal of Political Science 55: 767-781.

Bertelli A. M., Mason D. P., Connolly J. M. and Gastwirth D. A. (2015) Measuring Agency Attributes with Attitudes Across Time: A Method and Examples Using Large-Scale Federal Surveys. Journal of Public Administration Research and Theory 25(2): 513-544.

Brewer G. A. and Selden S. C. (2000) Why Elephants Gallop: Assessing and Predicting Organizational Performance in Federal Agencies. Journal of Public Administration Research and Theory 10(4): 685-712.

Clinton J. D., Bertelli A., Grose C., Lewis D. E. and Nixon D. C. (2012) Separated Powers in the United States: The Ideology of Agencies, Presidents, and Congress. American Journal of Political Science 56(2): 341-354.

Clinton J. D., Jackman S. and Rivers D. (2004) The Statistical Analysis of Roll Call Data. The American Political Science Review 98(2): 355-370.

Dodd L. C. and Schott R. L. (1979) Congress and the Administrative State. New York, NY: John Wiley \& Sons.

Eisenhardt K. M. (1989) Agency Theory: An Assessment and Review. Academy of Management Review 14(1): 57-74.

Epstein D. and O'Halloran S. (1996) Divided Government and the Design of Administrative Procedures: A Formal Model and Empirical Test. The Journal of Politics 58(2):373-397. (1999) Delegating Powers: A Transaction Cost Politics Approach to Policymaking Under Separate Powers. Cambridge: Cambridge University Press.

Ferejohn J. and Shipan C. (1990) Congressional Influence on Bureaucracy. Journal of Law, Economics, \& Organization 6: 1-20.

Fernandez S. (2005) Developing and Testing an Integrative Framework of Public Sector Leadership: Evidence from the Public Education Arena. Journal of Public Administration Research and Theory 15(2): 197-217. 
Finer H. (1941) Administrative Responsibility in Democratic Government. Public Administration Review 1: 335-350.

Frey B. S. and Oberholzer-Gee F. (1997) The Cost of Price Incentives: An Empirical Analysis of Motivation Crowding-Out. The American Economic Review 87(4): 746-755.

Friedrich C. J. (1940) Public Policy and the Nature of Administrative Responsibility. In Friedrich C. J. and Mason E. S. (eds.), Public Policy. Cambridge, MA: Harvard University Press, 3-24.

Gagné M. and Deci E. L. (2005) Self-Determination Theory and Work Motivation. Journal of Organizational Behavior 26(4): 331-362.

Gailmard S. (2009) Multiple Principals and Oversight of Bureaucratic Policy-Making. Journal of Theoretical Politics 21: 161-186.

Gailmard S. and Patty J. W. (2007) Slackers and Zealots: Civil Service, Policy Discretion, and Bureaucratic Expertise. American Journal of Political Science 51(4): 873-889.

(2012) Learning While Governing: Expertise and Accountability in the Executive Branch. Chicago, IL: University of Chicago Press.

Gilmour R. S. and Halley A. A. (eds.), (1994) Who Makes Public Policy?: The Struggle for Control Between Congress and the Executive. Chatham, NJ: Chatham House Publishers.

Grimmer J. and Stewart, B. M. (2013) Text as Data: The Promise and Pitfalls of Automatic Content Analysis Methods for Political Texts. Political Analysis 21(3): 267-297.

Hackman J. R. and Oldham G. R. (1976) Motivation Through the Design of Work: Test of a Theory. Organizational Behavior and Human Performance 16(2): 250-279.

Hopkins D. J. and King G. (2010) A Method of Automated Nonparametric Content Analysis for Social Science. American Journal of Political Science 54(1): 229-247.

Houston D. J. (2009) Motivating Knights or Knaves? Moving Beyond Performance-Related Pay for the Public Sector. Public Administration Review 69(1): 43-57.

Huber J. D. and Shipan C. R. (2002) Deliberate Discretion? The Institutional Foundations of Bureaucratic Autonomy. Cambridge: Cambridge University Press.

Judge T. A., Thoresen C. J., Bono J. E. and Patton G. K. (2001) The Job Satisfaction-Job Performance Relationship: A Qualitative and Quantitative Review. Psychological Bulletin 127(3): 376-407.

Kiewiet R. and McCubbins M. (1991) The Logic of Delegation: Congressional Parties and the Appropriation Process. Chicago, IL: University of Chicago Press.

Kriner D. and Schickler E. (2013) The Policy Consequences of Congressional Investigations. Paper presented at the Annual Meeting of the Midwest Political Science Association, Chicago, IL, April.

Kriner D. and Schwartz L. (2008) Divided Government and Congressional Investigations. Legislative Studies Quarterly 33: 295-322.

Lee J., Rainey H. G. and Chun Y. (2009) Of Politics and Purpose: Political Salience and Goal Ambiguity of U.S. Federal Agencies. Public Administration 87: 457-484.

Lee S.-Y. and Whitford A. B. (2013) Assessing the Effects of Organizational Resources on Public Agency Performance: Evidence from the US Federal Government. Journal of Public Administration Research and Theory 23(3): 687-712.

Light P. C. (1993) Monitoring Government: Inspectors General and the Search for Accountability. Washington, DC: The Brookings Institution.

(2006) The Tides of Reform Revisited: Patterns in Making Government Work, 1945-2002. Public Administration Review 66(1): 6-19.

MacDonald J. A. and McGrath R. J. (forthcoming) Retrospective Congressional Oversight and the Dynamics of Legislative Influence over the Bureaucracy. Legislative Studies Quarterly (in press). 
Markon J., Nakashima E. and Crites A. (2014) Top-Level Turnover Makes it Harder for DHS to Stay on Top of Evolving Threats, http://www.washingtonpost.com/politics/top-level-turnovermakes-it-harder-for-dhs-to-stay-on-top-of-evolving-threats/2014/09/21/ca7919a6-39d7-11e49c9f-ebb47272e40e_story.html (accessed 8 January 2015).

Martin A. D. and Quinn K. M. (2002) Dynamic Ideal Point Estimation Via Markov Chain Monte Carlo for the U.S. Supreme Court, 1953-1999. Political Analysis 10(2): 134-153.

Mathieu J. E. and Zajac D. M. (1990) A Review and Meta-Analysis of the Antecedents, Correlates, and Consequences of Organizational Commitment. Psychological Bulletin 108(2): 171-194.

May P. J., Jochim A. E. and Sapotichne J. (2011) Constructing Homeland Security: An Anemic Policy Regime. Policy Studies Journal 39(2): 285-307.

May P. J., Sapotichne J. and Workman S. (2009) Widespread Policy Disruption: Terrorism, Public Risks, and Homeland Security. Policy Studies Journal 37(2): 171-194.

May P. J., Workman S. and Jones B. D. (2008) Organizing Attention: Responses of the Bureaucracy to Agenda Disruption. Journal of Public Administration Research and Theory 18(4): 517-541.

Mayhew D. R. (2005) Divided We Govern: Party Control, Lawmaking, and Investigations, 1946-1990, 2nd ed. New Haven, CT: Yale University Press.

McCubbins M. D. and Schwartz T. (1984) Congressional Oversight Overlooked: Police Patrols Versus Fire Alarms. American Journal of Political Science 28(1): 165-179.

McGrath R. J. (2013) Congressional Oversight Hearings and Policy Control. Legislative Studies Quarterly 38(3): 353-380.

Meier K. J. (1975) Representative Bureaucracy: An Empirical Analysis. American Political Science Review 69: 526-542.

(1997) Bureaucracy and Democracy: The Case for More Bureaucracy and Less Democracy. Public Administration Review 57(3): 193-199.

Meier K. J. and Nigro L. G. (1976) Representative Bureaucracy and Policy Preferences. Public Administration Review 36(4): 458-469.

Meyer J. P., Stanley D. J., Herscovitch L. and Topolnytsky L. (2002) Affective, Continuance, and Normative Commitment to the Organization: A Meta-Analysis of Antecedents, Correlates, and Consequences. Journal of Vocational Behavior 61(1): 20-52.

Miller G. J. (2005) The Political Evolution of Principal-Agent Models. Annual Review of Political Science 8: 203-225.

Moe T. M. (1989) The Politics of Bureaucratic Structure. In Chubb J. and Peterson P. (eds.), Can the Government Govern?. Washington, DC: Brookings Institution, 267-329.

Ogul M. S. and Rockman B. A. (1990) Overseeing Oversight: New Departures and Old Problems. Legislative Studies Quarterly 15: 5-24.

Oleszek W. J. (2001) Congressional Procedures and the Policy Process., 5th ed. Washington, DC: CQ Press.

O'Toole L. J. and Meier K. J. (1999) Modeling the Impact of Public Management: Implications of Structural Context. Journal of Public Administration Research and Theory 9(4): 505-526.

Parker D. C. W. and Dull M. (2009) Divided We Quarrel: The Politics of Congressional Investigations. Legislative Studies Quarterly 34: 319-345.

Parnell A. (1980) Congressional Interference in Agency Enforcement: The IRS Experience. Yale Law Journal 89(7): 1360-1394.

Perry J. L. and Wise L. R. (1990) The Motivational Bases of Public Service. Public Administration Review 50(3): 367-373.

Pham H. H., Ginsburg P. B. and Verdier J. M. (2009) Medicare Governance and Provider Payment Policy. Health Affairs 28(5): 1382-1394. 
Rainey H. G. and Steinbauer P. (1999) Galloping Elephants: Developing Elements of a Theory of Effective Government Organizations. Journal of Public Administration Research and Theory 9(1): 1-32.

Riketta M. (2002) Attitudinal Organizational Commitment and Job Performance: A Meta-Analysis. Journal of Organizational Behavior 23(3): 257-266.

Rosenbloom D. H. (1993) Editorial: Have an Administrative Rx? Don't Forget the Politics!. Public Administration Review 53(6): 503-507.

Ryan R. M. and Deci E. L. (2000) Self-Determination Theory and the Facilitation of Intrinsic Motivation, Social Development, and Well-Being. American psychologist 55(1): 68-78.

Shapiro S. A. (1994) Political Oversight and the Deterioration of Regulatory Policy. Administrative Law Review 46(1): 1-40.

Shipan C. R. (2004) Regulatory Regimes, Agency Actions, and the Conditional Nature of Congressional Influence. American Political Science Review 98(3): 467-480.

Smith K. (2003) The Growth of Congressional Oversight. Paper presented at the 2003 meeting of the American Political Science Association, 27 August 2003, Philadelphia, PA.

Spector P. E. (1986) Perceived Control by Employees: A Meta-Analysis of Studies Concerning Autonomy and Participation at Work. Human Relations 39(11): 1005-1016.

Tepper B. J. (2000) Consequences of Abusive Supervision. Academy of Management Journal 43(2): 178-190.

(2007) Abusive Supervision in Work Organizations: Review, Synthesis, and Research Agenda. Journal of Management 33(3): 261-289.

Tett R. P. and Meyer J. P. (1993) Job Satisfaction, Organizational Commitment, Turnover Intention, and Turnover: Path Analyses Based on Meta-Analytic Findings. Personnel Psychology 46(2): 259-293.

Volden C. (2002) Delegating Power to Bureaucracies: Evidence from the States. Journal of Law, Economics, \& Organization 18(1): 187-220.

Waldo D. (1948) The Administrative State. Teaneck, NJ: Holmes \& Meier Publishers.

Ward K. D. (2014) Cultivating Public Service Motivation Through AmeriCorps Service: A Longitudinal Study. Public Administration Review 74(1): 114-125.

Weingast B. R. and Moran M. J. (1983) Bureaucratic Discretion or Congressional Control? Regulatory Policymaking by the Federal Trade Commission. The Journal of Political Economy 91(5): 765-800.

Whitford A. B. (2005) The Pursuit of Political Control by Multiple Principals. Journal of Politics 67(1): 28-49.

Wilson J. Q. (1989) Bureaucracy: What Government Agencies Do and Why They Do It. New York, NY: Basic Books.

Wilson W. (1887) The Study of Administration. In Shafritz J. M. and Hyde A. C. (eds.), Classics of Public Administration, 6th ed. Boston, MA: Thomson Wadsworth, 16-28.

Wolf P. J. (1993) A Case Survey of Bureaucratic Effectiveness in US Cabinet Agencies: Preliminary Results. Journal of Public Administration Research and Theory 3(2): 161-181.

Wood B. D. and Bohte J. (2004) Political Transaction Costs and the Politics of Administrative Design. Journal of Politics 66: 176-202.

Wooldridge J. M. (2010) Econometric Analysis of Cross Section and Panel Data. Cambridge, MA: MIT Press. 